Institute of $\mathbf{F}_{\text {ood and }} \mathbf{A g r i c u l t u r a l}_{\text {ciences }}$

\title{
Housing As We Grow Older: Independent Choices ${ }^{1}$
}

Virginia Peart and Carolyn Wilken ${ }^{2}$

Most people (86 percent) want to "age in place" or stay in their own homes as long as they are able. Moving to a smaller home or housing that provides support for our physical limitations requires a lot of hard decisions: Is a change needed now or in the near future? What housing types are available? Which are affordable? How long will each housing type meet our needs which are always changing? Once the decision is made to change our housing arrangement more decisions must follow: Our possessions. What to keep? What to give away? What to throw away?

Before choosing any living arrangement, think about the ways you rely on others for help and how much you are able to manage by yourself. Since finances are important, you will need to consider costs. What can you afford now and in the future? Will this arrangement allow you to remain as independent as you wish for as long as possible?

\section{Stay Where You Are in Your Own Home}

This home may be one you have lived in for years or moved to after retiring. Take a closer look at the advantages and disadvantages of remaining in your own home.

\section{Advantages}

- You have spent years fixing up this home just the way you like it. It is an expression of you which may be difficult to leave.

- "Home is where the heart is." Your friends and relatives live nearby. You know this community, and you are active here. This home has memories for you.

- You have privacy, peace and quiet when you want it. You are independent here.

1. This document is Fact Sheet FCS 3188, a series of the Department of Family, Youth and Community Sciences, Florida Cooperative Extension Service, Institute of Food and Agricultural Sciences, University of Florida. Publication date: November 2002. First published: January 1994. Revised: November 2002. Originally published as AH-2. Please visit the EDIS web site at http://edis.ifas.ufl.edu

2. Adapted by Virginia Peart, former associate professor, Housing; revised by Carolyn Wilken, associate professor, Family Life; and reviewed by Nayda I. Torres, professor, Family and Consumer Economics, Department of Family, Youth and Community Sciences, Cooperative Extension Service, Institute of Food and Agricultural Sciences, University of Florida, Gainesville, 32611. 
- Your furniture fits this home and you can keep all of your possessions.

- You have plenty of space for visits from children, grandchildren, and friends.

- If you are a homeowner, your mortgage is paid off, or almost paid off, so you can afford to live here comfortably on a fixed income.

- You have friends and know where the stores are located.

\section{Disadvantages}

- In the future you may not be able to afford this home. Inflation may raise the cost of utilities, taxes, and repairs to more than you can afford.

- Maintenance may become a problem. Yard work and home repairs may become harder for you and hired help can be expensive and hard to find.

- The home is too big, and its rooms no longer meet your needs.

- The neighborhood has changed. Your friends and neighbors have moved.

- The neighborhood may not be as safe as it was in the past.

- The home is too far from stores, doctors and other necessities.

- Your children live too far away to visit.

- It may not be designed for your needs (stairs, no bath on first floor).
If you rent your home, you may enjoy the advantages of low maintenance costs and more freedom to change your housing as needed. On the other hand, your expenses may be more affected by inflation since rent may go up at any time.

Advance planning is often the key to making it possible for an older person to stay in his or her own home. If you are planning to stay, you might want to use your early retirement years to prepare your home for later years. You may want to take care of expensive repairs now to cut maintenance costs later. Or you might want to convert part of your home to an income-producing apartment.

Your ability to do these things will, of course, depend on your finances. There are a number of community support services that help older persons remain in their homes.

If you plan to move, what are your options?

\section{Condominiums}

One alternative similar to traditional home ownership is the condominium, which is growing in popularity. A condominium is an "apartment" you own. Condominium ownership is created when a buyer receives legal title to certain property, as well as an undivided share or interest in common areas and facilities of a building or project. This usually involves exclusive ownership of a dwelling unit and common ownership of such facilities as the land, exterior walls, roofs, party walls between units, elevators, halls, lobbies and other items as defined in the master deed. Owning a condominium has both advantages and disadvantages. 


\section{Advantages}

- It is one of the safest investments against inflation.

- It creates a form of forced saving as equity is built up.

- Monthly costs are not related to a landlord's overhead and profit.

- It provides income tax savings and more freedom to do what you want inside (and sometimes outside) than renting.

- Routine exterior, lot maintenance and upkeep are usually provided.

- You are less likely to be forced to move than if you are renting.

- You may jointly establish rules for the use of common areas and facilities.

- Common special services and facilities may be available at a small additional cost.

\section{Disadvantages}

- You may not share the interests or lifestyles of the other owners.

- The initial investment involves some financial risk and limits investment flexibility.

- Initial costs may be too expensive.

- Owners must pay a monthly upkeep and maintenance fee that could increase.

- To a certain degree, the overall operation of a condominium project depends upon the ability of individual owners to make wise decisions as a group.

- The rules established by the group may not be in the best interests of individual owners.

- Selling may involve considerable time and expense.

- Owners pay for shared special services and facilities even if they don't use them.

\section{Renting an Apartment}

Selling a home and renting an apartment is another alternative. Apartment living can be carefree, especially for someone who travels and doesn't want maintenance responsibilities.

\section{Advantages}

- Small initial investment involves a minimum financial risk and does not limit investment flexibility.

- Monthly costs are easier to predict since maintenance and repair costs are usually part of the tenant's rent.

- No outside upkeep.

- $\quad$ Freedom to move or travel.

- It eliminates the trouble and expense of selling.

- Special services and facilities may be provided at little or no additional cost.

\section{Disadvantages}

- No equity is built up. 
- It usually provides less income tax savings than buying.

- Part of the rent is for the landlord's overhead, such as vacancy costs and profit.

- Tenant activities and improvements may be restricted by the lease, such as not allowing pets.

- The tenant may be evicted or the lease may not be renewed. This is especially a problem when older apartments are converted to condominiums.

- Special services and facilities add to rent costs even though they may not be used.

- Usually provides less space than a house.

- May not have a garden or large, private outdoor space.

\section{Subsidized Housing}

In recent years, many communities have built subsidized housing complexes for older people on limited incomes. These include high-rise apartments, older buildings that have been converted into apartments, and small apartment complexes.

\section{Advantages}

- Rents are subsidized and therefore lower (generally 25 percent of one's income).

- Complexes are designed with safety and convenience features.

- Maintenance and repair work are provided.
- Recreation and social activities can help residents make new friends.

- May be safer and less noisy than in family housing complexes.

\section{Disadvantages}

- Units are usually small and provide less space than your former home.

- Short supply of units may require being on a waiting list for several years in some areas.

- Some people don't like living only with senior citizens.

- May not be safer and less noisy than in family housing complexes.

- Town residence requirements can restrict occupancy eligibility.

\section{Purchase or Rent a Mobile Home}

Mobile home living has been very popular with older persons in recent years. Lower cost is a major reason. Another appeal is the neighborly atmosphere of some mobile home parks. Many of these parks are exclusively for retired persons. A mobile home can, if zoning permits, be located on your own lot in the country and placed on a permanent foundation or even a basement.

\section{Advantages}

- Purchase price is usually lower (per square foot) than for other types of homes.

- Convenient to purchase since the price usually includes appliances and furniture. 
- Initial investment (down payment) is low.

- Special services and facilities may be provided at little additional cost (if placed in a park).

- May be moved to another location

\section{Disadvantages}

- Average resale value may depreciate more than for other homes.

- Resale may be difficult to handle through conventional mortgage lenders.

- Initial purchase price usually does not include essential accessories, such as steps or skirting.

- Monthly costs may be expensive because of higher interest rates, insurance costs, and park rental fees if the home is placed in a park.

- Zoning may not allow setting the home on the buyer's land.

- Well-planned mobile home parks may not be available.

- Unless properly anchored, wind poses a serious threat.

- It is expensive to move a mobile home.

- Maintenance and upkeep require time and energy.

\section{Retirement Villages or Communities}

Retirement villages are a relatively new concept. These communities are built exclusively for retired people and isolate them from the noise and bustle of life among young families. Since comfort and friendship are important to this group, it is not surprising that recreational facilities such as golf courses and swimming pools are available. Libraries, craft workshops, and auditoriums may also be included. The physical setup and the kinds of services vary widely, as do the costs.

Business corporations, religious organizations, and other groups have sponsored retirement villages which are usually managed by developers or a management team. Housing types might include single-family detached homes, duplexes, townhouses and condominiums. They range in size from one to three bedrooms for rent or purchase. Advantages are that residents are assured of community life among others of similar age and, presumably, of compatible tastes. The major disadvantage may be the cost -- both the initial entrance cost and the monthly fee thereafter.

\section{Moving in With Others}

An older person and his children or other relatives or friends may decide to live together. An older parent who is alone may move in with relatives for companionship. Both generations may benefit by living together -- an older woman escapes loneliness by living with her son's family, and helps out by babysitting for her grandchildren. This arrangement allows her daughter-in-law to pursue a career.

Older adults may find it economical to pool their financial resources by combining households, or they may simply get along well and enjoy living together in a shared 
household. In this arrangement, each person has his or her own room and shares the rest of the house with others. Some housekeeping and even food services may be provided. Living together is not necessarily the right option for everyone, however. You might want to discuss this idea openly and honestly with everyone involved first, since all -parents, adult children, grandchildren and housemates -- will be affected by the change.

If possible, it's best to take time and think about this option carefully before a crisis imposes a hasty decision on you. You might even want to try living together for a few months before you make a permanent change.

\section{Advantages}

- Security

- Companionship
- Less expensive than maintaining a home.

- Less time needed for maintenance since tasks are shared.

- Can help each other with health care and business matters.

- Can travel without the worry and bother of closing your home.

\section{Disadvantages}

- Difficult to maintain privacy.

- Difficult to be independent.

- Chance for personality conflict. 